\title{
Pigeon-Raven and sperm whale, magical objects and domestic horned. The division of the world during the early neo-Neolithic in Western France.
}

\author{
Serge Cassen \\ CNRS, Laboratoire de Préhistoire et Protohistoire de l'Ouest de la France (UMR 6566), \\ Université de Nantes, serge.cassen@univ-nantes.fr
}

\begin{abstract}
We are going to demonstrate that it is possible to invest an Armorican stele of the $5^{\text {th }}$ millennium with an order of meanings in the same way as a language or a kinship system; in other words, a set of operations destined to ensure, between individuals and groups, a certain type of communication. But such demands necessitate modifying established patterns, because none agree on the idea that we have conceived of a peaceful passage to agriculture and animal husbandry on the Atlantic façade of Europe. Each fundamental sign on these standing stones will here be reconsidered, and their 'syntax' analysed. However, we have no innocence about the subject: as soon as we display the strange desire to question these engravings, we 'participate' in an analogical spell attributed to a distant image, we fall as well into those exegetic attempts which pretend to obey to a cultural project wherein it appears they interpret the symbolism but that, finally, tend to renew it, because any key to symbols is part of their symbolism. And even in an oneiric or fairy world, power does not derive from gratuitousness, but from coherence.
\end{abstract}

IZVLEČEK - Menimo, da je stele iz Armorike iz petega tisočletja pred našim štetjem moč umestiti v podoben sistem pomenov kot so jezik ali sorodstveni sistemi. Torej v množico operacij, ki omogočajo komunikacijo med posamezeniki in skupinami. Seveda to zahteva spremembo pogleda, saj je naš pogled na prehod $k$ kmetovanju na Atlantski obali Evrope drugačen od uveljavljenih. Pretresli bomo vsak znak, ki se pojavlja na stelah in analizirali njihovo sintakso. Tu ne moremo govoriti o teoretski nedolžnosti, saj takoj ko pokažemo čudno željo po razumevanju teh znakov, že sodelujemo v analoškem uroku preteklih podob. Eksegetski poskusi, ki zatrjujejo, da poskušajo razumeti simbolne sisteme, jih tako vzpostavljajo na novo, saj je ključ do razumevanja simbolov del njihovega simbolizma. Podobno kot v pravličnem svetu njihova moč ne izhaja iz njihove pojavnosti, temveč iz celote, ki jo tvorijo.

KEY WORDS - Stele; Brittany; carvings; early Neolithic

\section{INTRODUCTION}

We are going to demonstrate that it is possible to invest a engraved steles from Armorica in Britanny (Vth millennium cal BC) with an order of meanings in the same manner as languages or a kinship systems. This means a set of operations, destined to ensure a certain type of communication between individuals and groups. Our first task will be to clarify this communication in the case of Morbihan, where such order seems accessible to the archaeological processing of information. The questions we ask are: who is the transmitter and who the receiver; what is the relationship between these two actors, and why was everything enacted by the sea?

What is represented on the Armorican engraved steles? A symbol of immediate and present action, a 
myth, an expression of an imaginary past, or history, a record of the real past? It is known that these three cases can be described as the conjugation of the three senses, where each stratum conjugates its signs. We have learnt from linguists that signs taken separately do not have any meaning, that each of them represents a gap of meaning between itself and the others rather than it expresses a meaning. Because meaning can only exist in the difference. And, all systems of meaning are systems of relationships that we have henceforth to research.

It is a general question, when steles are taken as a point of departure in our understanding the early Neolithic steles with carvings that were recognized as a world of spirits, men, animals and things.

\section{A REVERSAL OF PERSPECTIVE}

Such demands expressed in a preamble necessitate modifying pre-established patterns, since no one agrees with the scenario that we have proposed to understand the passage to agriculture and animal husbandry on the Atlantic coast of France. No one can escape an advanced analysis of the confrontation between societies as diverse as hunters-fishermen on one side, and farmers and artisans of the agricultural way of life on the other. And this "rock art" considered in the archaeological literature is a negative revelation very efficient and very pitiless.

Even in an oneiric or fairy world, power force does not derive from gratuitousness, but from coherence.

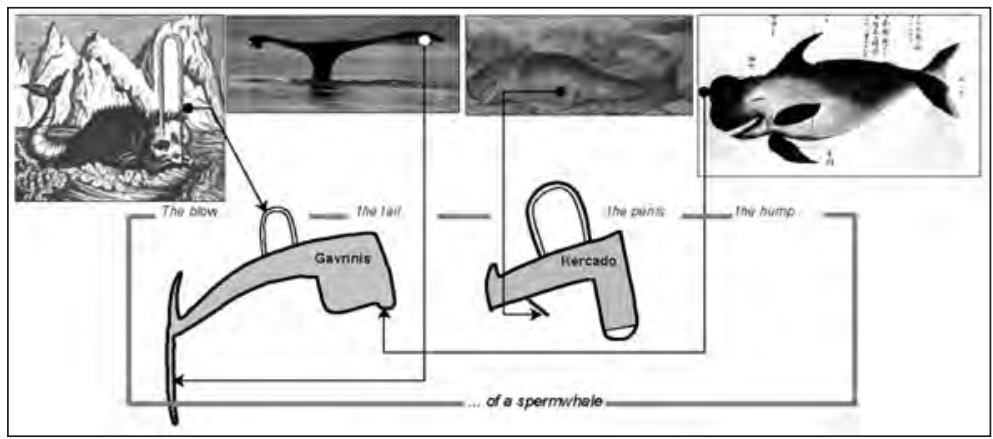

Fig. 2. Graphic units to recognize a sperm whale (after Cassen, Vaquero 2000, iconographic references included in this article).
Here is the coherence of a determined historical situation whose first obligation was to construct legitimacy (Cassen 1993; 2000a; Boujot, Cassen 1997).

We will place all signs in question at the beginning of the chain of comprehension, or at least in an equal participation in historical enquiry, and not at the end of the exercise, as something superfluous, inexplicable or less noble subject than the ceramic production "typologies" or a technical lithic subsystem that, together, would alone reveal traces of chronology and domestic meals, and therefore offer much less risky way of inquiry than this interpetation of images.

Then we will think about the materiality and position of the steles. The steles communicate between future and past, warn or commemorate. The steles demand an attitude, constrain the real or imaginary image of anyone who uses the space. The steles are frontiers and thresholds between two states, two spaces, two worlds, which are about to merge: the commemoration cancels alone the warning when the former is contemptible or superfluous. 


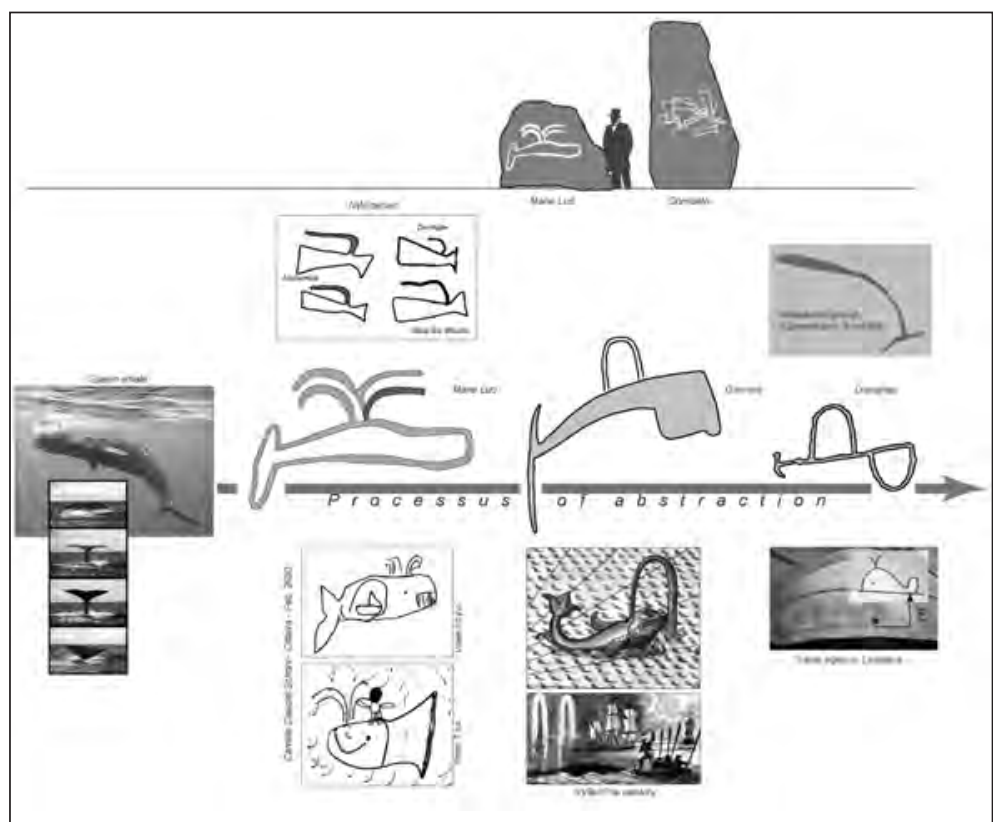

Fig. 3. The process of abstraction from the realistic image to the simple and fundamental lines of the animal; compare the same reprentation on the Neolithic steles of the Iberian Peninsula, according to the direction of the blow (directed to the left, instead of right in France with the exception of Dissignac, deliberately inverted here to facilitate comparison) (additional iconographic references are included in Cassen, Vaquero 2000).

But another preliminary question arises: why this sudden verticality in the establishment of such communication? No doubt: to resist by straightening up. Because, to establish a threshold in a space, it is necessary to display rebelliousness, a resistance and a reaction, by revealing an efficient action to counter and separate.

To activate this will, to straighten up by extending the body, this refusal to submit, to resist - a sensation, and the other, the chosen material will be of the highest importance. Then, as Bachelard tells us, a hard body that disperses all blows is the convex mirror of our energy, while the soft body is the concave mirror. The complex of Medusa is a petrified anger, the will of a wicked hypnotism that would like to order other people to the sources of the person with a word and a look. Materials and symbols give a possibility to reflect - a Church was built on a stone sometimes.

And we will review the system of recording, the fundamental base of our inquiries that marks each technical advance since the origin of the discipline. We are able to do this thanks to the advancements in digital image acquisition and processing that can record the imperceptible tiny traces and thanks to the restoration of the chaines opératoires for the extraction of stones and realization of engravings ( $C f$. Cassen, Merheb 2004; Mens 2002).

\section{AN ANALYSIS OF FORMS AND THINGS}

Established archaeology has recognized and manipulated these figures that appear on the stelles: the axe (tool and prestige good), the crook (badge of authority), the plough (tool), the woman (divinity) and horned animals (domestic assistants).

\section{The Mother-goddess}

We have first to transform a goddess into a bodily dirtiness to which it costs to look. A goddess of fertility? A goddess of beauty? A "tousled" goddess, as you can find in the literature, with huge ears... The mother-goddess, "Idol in a shield form"... What represents her, represents her in a huge form; she

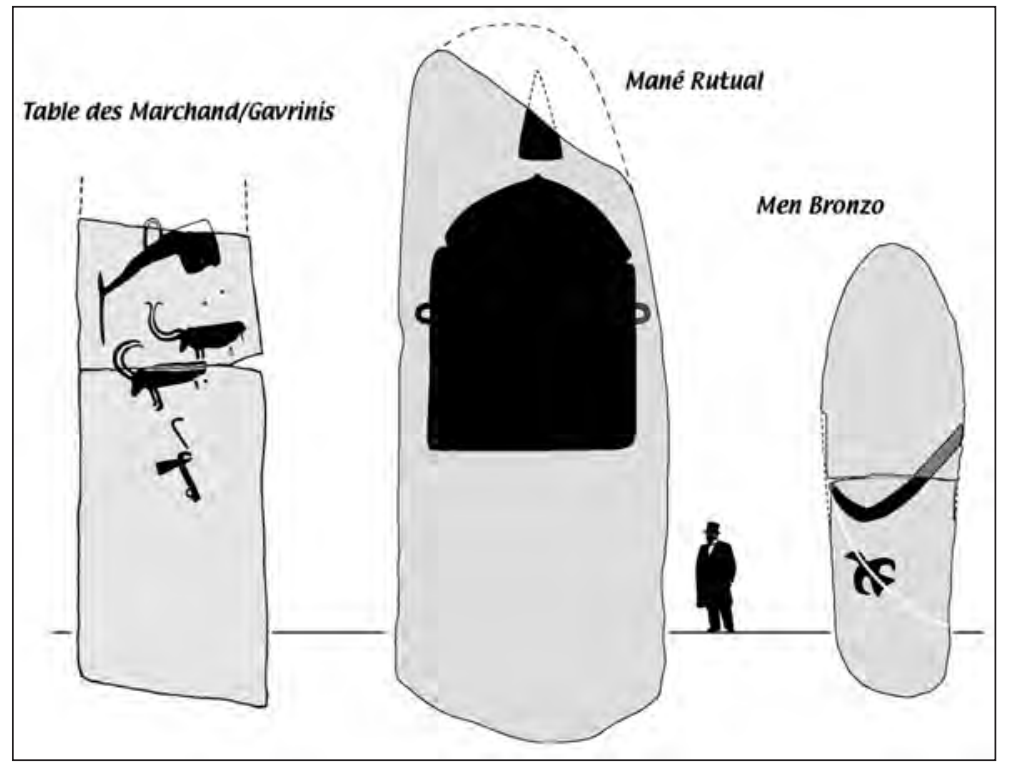

Fig. 4. The three steles from Locmariaquer (Morbihan) mentioned in the text: Table des Marchand/Gavrinis, Mané Rutual, Men Bronzo (after Boujot, Cassen 1993; Cassen, Vaquero 2003). 
occupies all the stele in the 'Mané Rutual'. If she derives from an anterior image, what is it? If she is a goddess, she has to be womanly, beautiful or deformed, but her gender has to be clarified. If an engraver in Brittany, able to successfully realize cows and axes, fails in a such manner in the representation of the pure beauty, this interpretation is no longer acceptable. This is not beauty, the essence of this gigantic goddess. Sexual attributes are always present in representation of the femininity. The exaggeration of buttocks, vulva and breasts are shorthand that have existed since the first representations. In this silhouette we are unable to recognize neither the wo-

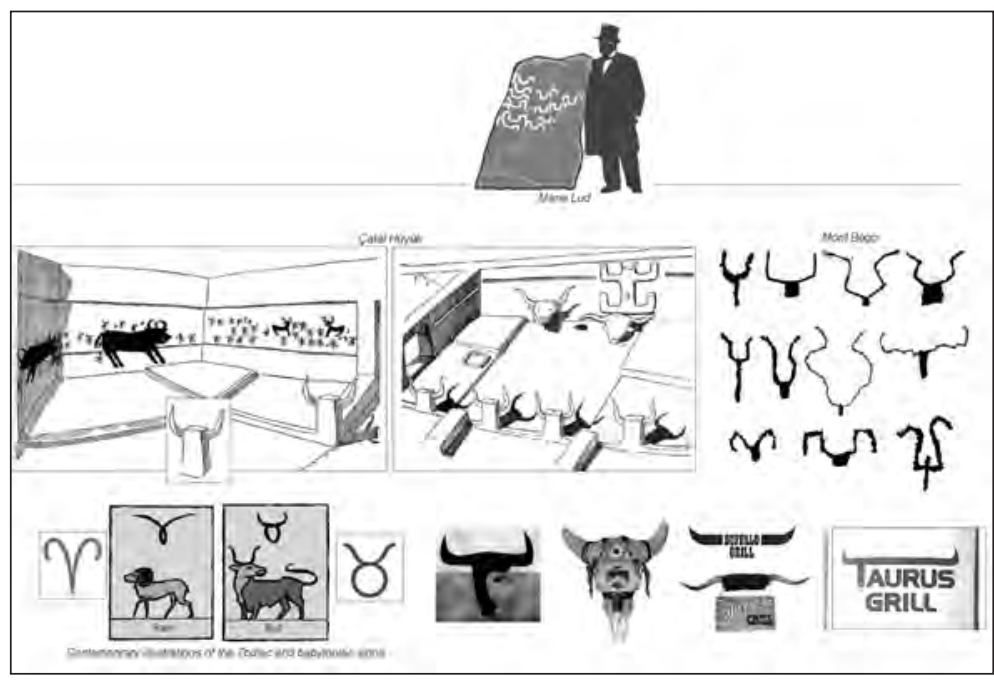

Fig. 5. From the realistic reprentation of a bull's head, or horned head, to an abstract sign (after Mellaart 1967, De Lumley et al. 1995). man, nor the goddess. It is a silhouette of something universal, as well as indisposed: a penis, represented erect before the observer (Cassen 2000b). The phallus on the stone redoubles the stele, redoubles its intention, and redoubles its image, intuitively captured as far as possible: an erection (Fig. 1).

\section{The Axe-plough}

We have to transform, secondly, a peasant's tool into a monster. How surprising is the plough that we see on some steles from the region. We will not find this object in excavations, neither it's representation that could have been used for comparison or that could have been interpreted as an original. Its strict appearances on the coastal sites, parallels with another similar motif from the Iberian Peninsula, and a meticulous formal analysis have transformed an agricultural implement into a sea animal, a sperm whale (Cassen, Vaquero 2000; 2004). Its hump, its tail in perspective, its blowhole, its quadrangular head, and its deployed penis are abstracted, as it is the case with any animal that it is hard to see (Figs. 2 and 3).

\section{The Crook}

The pastoral crook, perhaps Episcopal emblem, sometimes also an ordinary sickle, takes the role of a badge

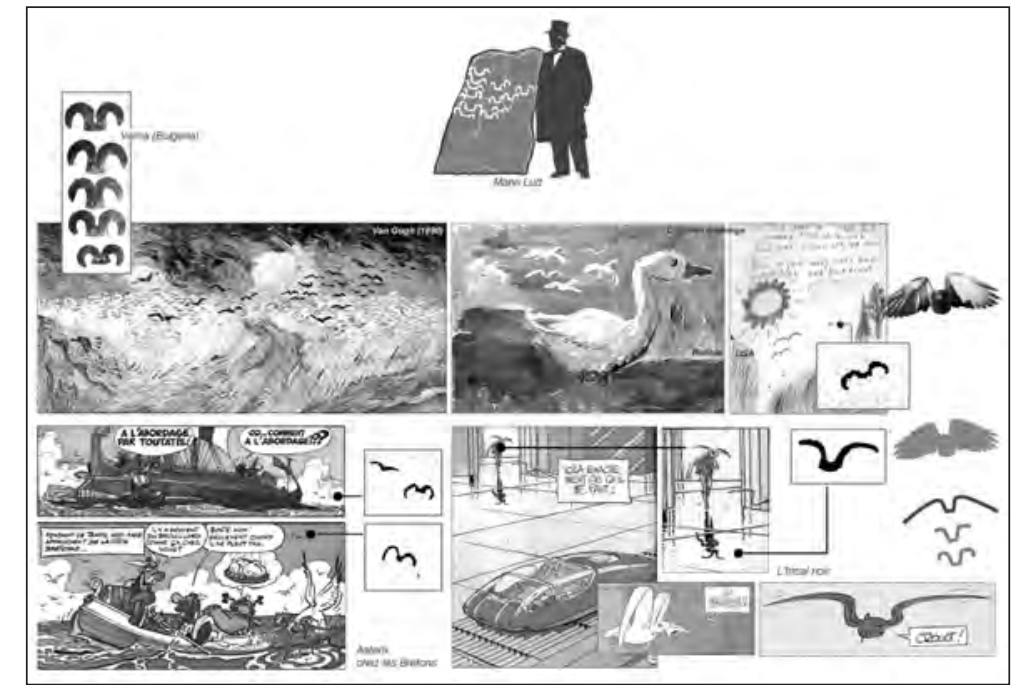

Fig. 6. Representation of birds in comics and children's drawings; analogies with the 'horned' from Varna (after Ivanov 1988; Moebius, Jodorowsky 1981; Gosciny, Uderzo 1986; http://ladoga.krc. karelia.ru/environ/ecosystems/fauna/birds/gooses/pictures/index .phtml); http://www.or.blm.gov/Medford/images/table_new/art11. jpg 
More generally, it is also a great benefit for prehistorians to follow in detail the process by which it no longer represents a simple hunter, as in Antiquity, but the protagonist of mythical hunts, no more a bygone weapon but a mythological badge (in Etruria, for example, with the $l i$ tuus; in Greece, with the lagobolon). Fearsomely efficient in the hands of a skilful hunter, we know that painted or engraved, from Australia and Africa, Europe to America, the crook of the throwing weapon seems to pass invariably from a representation of "action" within a narrative sequence to an ostentatious figure. And here and there, the same process repeats an irresistible transformation, evolving from the fundamental distance weapon - in the simplest form of throwing a stone to a hieratic emblem, an insignia of status, an weapon that will come to distinguish a divine king (Hittite, Egyptian, etc.) or a Siberian shaman

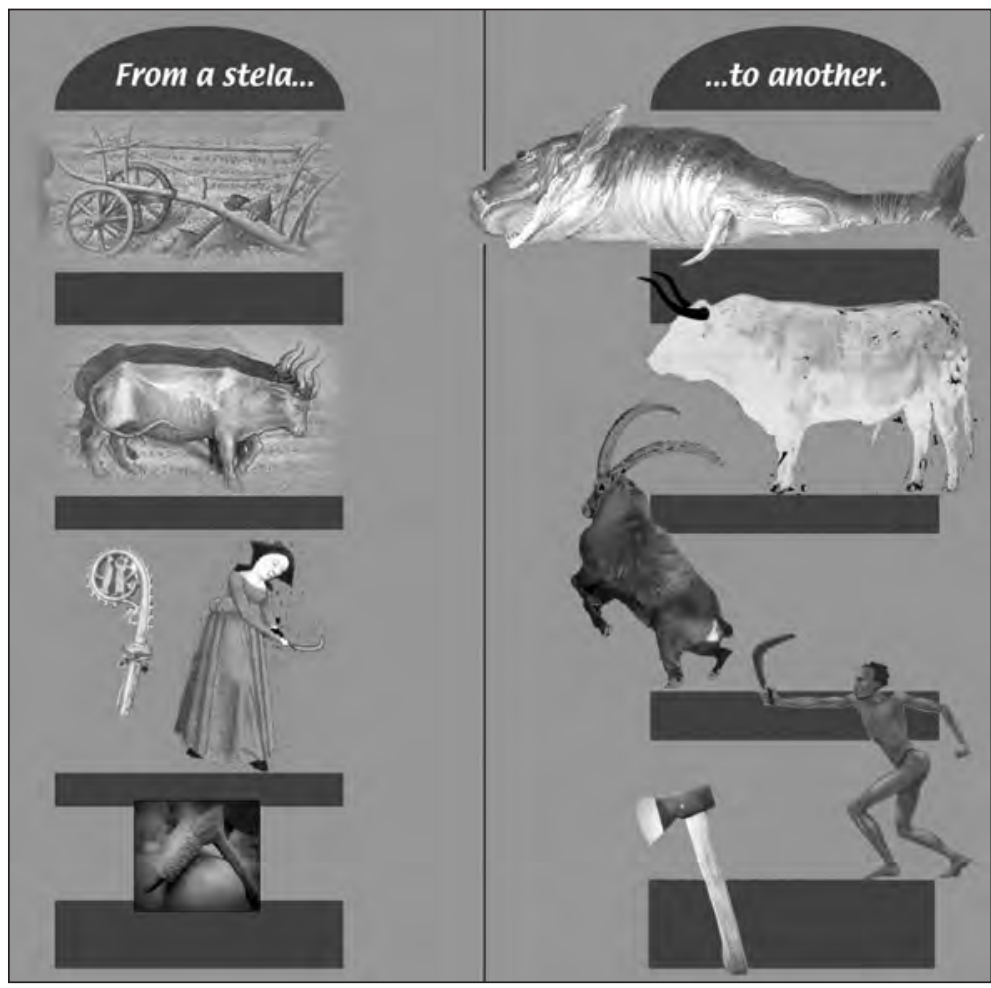

Fig. 7. From the usual peaceful representation to a violent association of arms and animals on the Table des Marchand/Gavrinis stele.
(Altai) by the fact, perhaps, that it does not spill blood.

\section{The Horned}

In Brittany the interpretations of this sign have been generally accepted in $19^{\text {th }}$ century. The interpretative model was so popular that it would be necessary to have a powerful arguments to contest it. This decisive argument was discovered on a stele in Locmariaquer (Morbihan), with the deciption of a "raised" bird in full flight, the head turned outwards (Fig. 4), superposed to a white quartz vein (Cassen, Vaquero 2003b). We will focus on this sign more than on the other signs (Cassen 2005). Above the bird, an immense crook, also processed in champlevé, bars his rising way, a form which was inventoried in the region thanks to some objects of similar morphology and comparable size (Petit Mont, Er Grah, etc.), but different from our identification because classified by archaeologists in the category of 'horned', others horned (Le Roux 1992).

A first empirical approach has allowed us to evaluate the obvious differences in the multitude of birds, even before evoking in detail the classifications of ornithologists. Finally, the alone possible confrontation obtained after our research was the opposi- tion between the colombidae and the corvidae. But argument against the last one is that neither the form of the beak, impressive in its length and its crookedness, nor the flight, sometimes similar to the raptors (the great raven), are visible in Locmariaquer.

But on the contrary, the flights of the raven and the crow are quite varied. It can be frequently observed that when they fly in groups, their wings are turned down in a similar roundness as on 'Men Bronzo'. This design is indeed a figure that we could connect with the "playing" ravens, executing some buckles, zooms and stung swirling.

However, neither the crow nor the raven have tails as straight, nor heads so round, or beaks so short as the engraved representation indicates. We therefore decide that this signs represents colombidae, especially the migratory pigeon.

But whatever the species, if a bird as clearly legible as the 'Men Bronzo' figure has played a decisive role in the mythical bestiary of the Armorican Neolithic (similar as its sea pendant, the sperm whale), no doubt it requires a scientific approach to reinterpret other signs as birds, which were previously badly understood. A representation of such importance in 
our interpretive pattern, unique in Brittany, can not reside isolated.

Within the group of inventoried signs (sperm whale; bovine and ovine snake; horned; "sheathed axe", blade and handled axe; crook; bow and arrow; phallus), we eliminate first the phallus and the animals, including the snake that, even stylized, seems impossible at first sight to confuse with the bird. objects, unanimously recognized, will not be among the pretenders (axes, bow and arrows). So, by subtraction, it is necessary to consider two exclusive interpretations: the "sheathed axe" or the horned.

The first, "sheated axe" is a composition where no analogous morphology as for bird can be found (Péquart, Le Rouzic 1927; Shee-Twohig 1981). The second interpretation was broadly accepted (Déchelette 1908) and, we would be pretentious to contest it. And yet... A cranium of bovid, perhaps of cervid, integrates systematically two meaningful graphic elements: a pair of horns, and a "head" (Fig. $5)$. No representation anywhere contradicts with this rule. The cases from alpine regions (Monte Bego in France, Val Camonica in Italia), the historical place par excellence for this type of representation do not contradict this assertion, too.

The "head" can be realistic, or square and massive, or on the other hand, reduced to a vertical line. The horns can be limited to simple jagged lines or developed in a filled hyperbole, while passing through the exact reproduction of the Morbihan "horned".

Nothing mentioned above appears in the Armorican corpus where the sign presents no structural analogy with the graphism of the real horned sign. We can claim correspondingly, from coherent and logical research based on the discovery of the 'Men Bronzo', that the only solution possible to the famous horned signs is a representation of a bird figured full face, in flight, with raised and deployed wings (Fig. 6).

\section{The Axe}

It is not only a simple tool for cutting down virgin forests, but most of all a new defense and attack weapon that acts in percussion lancée, the expression of the self by means of force, creating the shock of one body confronted with another. It will split better if the impact is violent. Slivers make a vivid noise, the fulgurance of knocks warms up the blade. The impetuous and sharp axe is expressive and without restriction. Here is the intense power of action and the expression of an weapon/tool, brutal and resonant, thundering and tumultuous.

And furthermore, where the stylized representation of an adze in the form of a cross, can be recognized in as representation of human form (Mané Lud; Péquart, Rouzic 1927; Cassen et al. 2005). Its cruciform figuration corresponds to the universal disposition of the static body where legs are joints and where arms are tended in the lateral and opposite directions and not to the form of the figure of the "orant", with arms raised to the sky and legs parted by a symmetrical and similar opening of the body, a body which is no more oriented in the same manner. In our opinion this can only be "Man of stone" (Gouletquer 2001).

\section{A new order of meanings - an other type of communication (Fig. 7)}

These engraved signs are the expression of a myth, a message about the world, about life and death, and because it supposes adherence to spoken words, it expresses both the knowledge and beliefs of oral societies. The myth tells a sacred history, returned sometimes to a real history, and undergoes in its transformation, the vagaries of the history lived. The myth ensures the system of oppositions by the intervention in the indistinct.

Let's take the stele of 'Table des Marchand' as an operative example: to observe and to construct such a system, used by anthropologists. The separation 


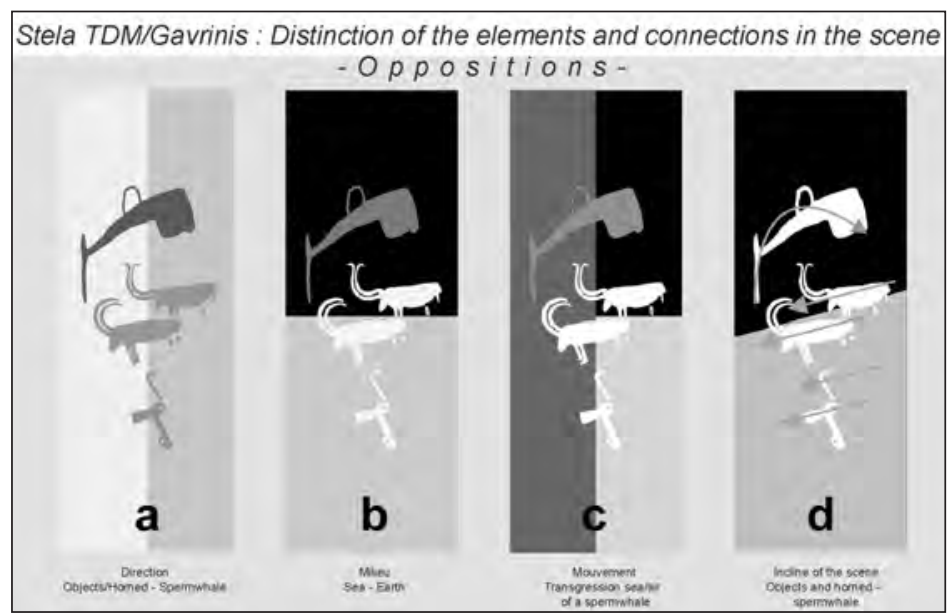

Fig. 9. The stele of Table des Marchand/Gavrinis (Morbihan): structural analysis of the signs (after Cassen, Vaquero 2003). opposition of a milieu between the sea and the earth; (c) a contrast of movement, where a sperm whale transgresses the air, flying over the ocean and the seashore, and (d) flying above animals and weapons which present and oppose their forms and their active and functional elements (horns, blades) according to a slope in direction and relation to the sea, as the sea in a lower part of the composition (Fig. 9).

Here, on the edge of the Ocean, in a reversed order of weightlessness, a sperm whale exits flying from and over the unknown and confronts with the arms of humans and with the animals of men works as an opposition between things and animals and, between a savage marine animal, two terrestrial animals, and the objects of men, made by men. It creates spatial composition, (3) the sperm whale, and under it, two couples formed by a bovine and a crook, and a ram accompanied by an axe; the ram is engraved on the bull, in a second moment, while the axe is also engraved on the crook, in a same secondary process which is 'promoting'» a figure to the detriment of the other, in addition to the visible hierarchy of positions, which presents the ram and the axe before the bull and the crook, placed in a retiring situation (Cassen, Vaquero 2003a; Cassen 2005) (Fig. 8).

We are facing (a) an opposition of directions, between a sperm whale on one hand, head opposed to the right, and objects and animals on the other hand, heads and blades directed to the left; (b) an
(Table des Marchands). While a crook in full down thrust of its tedious touch hinders a knock down of pigeon coming from the southern horizon ('Men Bronzo') and, in the same time, a gigantic phallus' gland opposed to the active sharpness of the axe ('Mané Rutual').

Here are restrictive images proclaim hierarchies and power, cosmological myths also answering the question: who are the most powerful, gods or angels, man or animal?... So many aetiological myths legitimate the beginning is also the world of the government. Worked out by our symbolic activity, transcendence is the projected image of this shared desire for power, and the confession of our impotence. For the god or the gods, it is the first and essential value and attribute of the deity, that is symbolized by a wing, a tooth, a horn, a meteor, an axe or a boomerang... the order of the sovereignty...because the world of

\section{REFERENCES}

BACHELARD G. 1947. La Terre et les rêveries de volonté, Essai sur l'imagination de la matière. Paris.

BOUJOT C., CASSEN S. 1993. Los Problemas cronologicos del Megalitismo en la fachada atlantica de Francia. Cuadernos de Prehistoria y Arqueología Castellonenses 15: 127-141.

1997. Néolithisation et monumentalité funéraire: explorations du tertre de Lannec er Gadouer à Erdeven (Morbihan, France). In R. Casal (ed.), $O$ Neolitico atlantico e as orixes do Megalitismo. Actas do coloquio internacional: 211-232.
CASSEN S. 1993. Le Néolithique le plus ancien de la façade atlantique de la France. Munibe (Anthropologia-Arkeologia) 45: 119-129.

2000a. Funerary stelas reused in the passage graves of western France: history of research and sexualisation of the carvings. In A. Ritchie (ed.), Neolithic Orkney in its european context. McDonald Institute Monographs. Cambridge: 233-246.

2000b. La Forme d'une déesse. In Eléments d'architecture (Exploration d'un tertre funéraire à Lannec er Gadouer, Erdeven, Morbihan. Constructions 
et reconstructions dans le Néolithique morbihannais. Propositions pour une lecture symbolique). Mémoire 19: 657-672.

2000c. La crosse, lacrosse. In Eléments d'architecture (Exploration d'un tertre funéraire à Lannec er Gadouer, Erdeven, Morbihan. Constructions et reconstructions dans le Néolithique morbihannais. Propositions pour une lecture symbolique). Mémoire 19: 673- 678.

2005. Pigeon-vole! Re-connaissance d'une gravure armoricaine du Ve millénaire. Bulletin de la Socété Préhistorique Française 102, 2: 299-334.

forthcoming 2005. Un pour tous, tous contre un... Symboles, mythe et histoire à travers une stèle morbihannaise du Ve millénaire. In A. Testart, L. Barray, P. Brun (eds.), Pratiques funéraires et sociétés. 12-14 juin 2003 (UMR 5594, UMR 7041, Laboratoire d'Anthropologie sociale, Collège de France; Centre de Recherche et d'Etude du Patrimoine, Sens).

CASSEN S., VAQUERO LASTRES J. 2000. La Forme d'une chose. In Eléments d'architecture (Exploration d'un tertre funéraire à Lannec er Gadouer,Erdeven, Morbihan. Constructions et reconstructions dans le Néolithique morbihannais. Propositions pour une lecture symbolique). Mémoire 19: 611-656.

2003a. Le Désir médusé. In Guilaine (ed.), Expressions symboliques, manifestations artistiques du Néolithique et de la protohistoire. Séminaires $d u$ Collège de France: 91-118.

2003b. Construction et deconstruction des surfaces sur les temps. Enregistrement et représentation de stèles gravées: Le Bronzo en Locmariaquer et Vieux Moulin en Plouharnel (Morbihan). Rev. Archéo. de l'ouest, 20: 109-125.

2004. Fabulous Things. Iberian Journal of Archaeology 6: 7-48.

CASSEN S., MERHEB M. 2004. Archiving Neolithic heritage. Paris, International Conference 3rdDiMENSIon 2004, The standing appointment for professionals in 3D scanning solutions: 6-15. (Publication on CR-Rom).

CASSEN S., LEFEBVRE B., VAQUERO LASTRES J., COLLIN C. 2005. Le Mané Lud en sauvetage (Locmariaquer, Morbihan). Enregistrement et restitution de si- gnes gravés dans une tombe à couloir néolithique. L'Anthropologie 109: 325-384.

DECHELETTE J. 1928 (1908). Manuel d'Archéologie préhistorique et celtique. 1 - Archéologie préhistorique. Lib. Picard. Paris.

GALLES R., MAURICET M. 1864b. Étude sur le ManeLud en Locmariaquer. Vannes: Imp. Galles, 1864.

GOSCINY R., UDERZO A. 1966. Astérix chez les bretons. Dargaud. Paris.

GOULETQUER P. 2001. Rêves de pierre. In J. Y. Eveillard (ed.), La pierre en Basse-Bretagne: usages et représentations. Cahiers de Bretagne Occidentale 18: 135-144.

IVANOV I. 1988. Das Gräberfeld von Varna - Katalog. Macht, Herrschaft und Gold. Das Gräberfeld von Varna (Bulgaria) und die Anfänge einer neuen europäischen Zivilisation. Saarbrücken 1988: 189-208.

LE ROUX C. T. 1992. Cornes de pierre.... In Paysans et Bâtisseurs. L'émergence du Néolithique atlantique et les origines du Mégalithisme. Actes du XVIIe colloque interrégional sur le Néolithique. Vannes 2931 octobre 1990. Revue Archéo. de l'Ouest, Supp. $n^{\circ}$ 5: 237-244.

LUMLEY H. (de), ECHASSOUX A., SERRES T. 1995. Signification des gravures corniformes du Chalcolithique et de l'âge du Bronze de la région du Mont Bego. Bull. d'Etudes préhist. et archéol. Alpines: 79-141.

MELLAART J. 1967. Catal Hüyük, a neolithic town in Anatolia. Thames \& Hudson. London.

MENS E. 2002. L'affleurement partagé. Gestion du matériau mégalithique et chronologie de ses représentations gravées dans le Néolithique moyen armoricain. Thèse de doctorat (nouveau régime), Université de Nantes, 3 vol.

PEQUART M, PEQUART St-J., LE ROUZIC Z. 1927. Corpus des signes gravés des monuments mégalithiques du Morbihan. Paris.

SHEE TWOHIG E. 1981. The Megalithic Art of western Europe. Clarendon Press. Oxford. 